\title{
Psychodramatic psychotherapy combined with pharmacotherapy in major depressive disorder: an open and naturalistic study
} Psicoterapia psicodramática combinada ao tratamento medicamentoso no transtorno depressivo maior: um estudo aberto e naturalístico

\author{
Elisabeth Maria Sene Costa, ${ }^{1}$ Rosilda Antonio, ${ }^{1}$ Márcia Britto de Macedo Soares, ${ }^{2}$
} Ricardo Alberto Moreno ${ }^{1}$

\begin{abstract}
Objective: Recent literature has highlighted the role of psychotherapy in the treatment of major depressive disorder. Combined therapies comprising both psychotherapy and pharmacotherapy have presented the best results. Although several kinds of psychotherapies have been studied in the treatment of depressive disorders, there remains a lack of data on psychodramatic psychotherapy in the treatment of major depressive disorder. The objective of this study was to evaluate the impact of psychodramatic psychotherapy (in a sample of major depressive disorder patients. Method: This is an open, naturalistic, controlled, non-randomized study. Twenty major depressive disorder patients (according to the DSM-IV criteria), under pharmacological treatment for depression, with Hamilton Depression Scale total scores between 7 and 20 (mild to moderate depression), were divided into two groups. Patients in the psychotherapeutic group took part in 4 individual and 24 structured psychodramatic group sessions, whilst subjects in the control group did not participate in this psychodramatic psychotherapy. Both groups were evaluated with the Social Adjustment Scale - Self Report and the Hamilton Depression Scale. Results: Psychotherapeutic group patients showed a significant improvement according to the Social Adjustment Scale - Self Report and the Hamilton Depression Scale scores at endpoint, compared to those of the control group. Conclusions: Results suggest that individual and group psychodramatic psychotherapy, associated to pharmacological treatment, provides good clinical benefits in the treatment of major depressive disorder.
\end{abstract}

Keywords: Major depressive disorder; Psychotherapy; Psychodrama; Group practice; Social adjustment

\section{Resumo}

Objetivo: A literatura recente destaca o papel das psicoterapias no tratamento do transtorno depressivo maior. A combinação de psicoterapia e farmacoterapia apresenta os melhores resultados. Vários tipos de psicoterapias têm sido estudados no tratamento dos transtornos depressivos; no entanto, existem poucos dados sobre a psicoterapia psicodramática no tratamento do transtorno depressivo maior. O objetivo deste estudo foi o de avaliar o impacto da psicoterapia psicodramática em uma amostra de pacientes com transtorno depressivo maior. Método: Este estudo constituiu-se de um ensaio clínico controlado, naturalístico, não-randomizado e aberto. Vinte pacientes com transtorno depressivo maior (de acordo com os critérios do DSM-IV), em tratamento farmacológico para depressão, com escores na Escala de Depressão de Hamilton entre 7 e 20 (depressão leve a moderada), foram divididos em dois grupos. Os pacientes do grupo psicoterápico participaram de quatro sessões individuais de psicoterapia psicodramática e 24 sessões de psicoterapia psicodramática em grupo. Os pacientes do grupo controle não participaram de sessões de psicoterapia psicodramática. Ambos os grupos foram avaliados pela Escala de Depressão de Hamilton e pela Escala de Auto-avaliação de Adequação Social. Resultados: Os pacientes que participaram de sessões de psicoterapia psicodramática apresentaram uma melhora significativa nos escores da Escala de Depressão de Hamilton e da Escala de Auto-avaliação de Adequação Social, comparados aos pacientes do grupo controle. Conclusões: Os resultados sugerem que a psicoterapia psicodramática individual ou em grupo, associada ao tratamento farmacológico, proporciona bons resultados no tratamento do transtorno depressivo maior.

\section{Descritores: Transtorno depressivo maior; Psicoterapia; Psicodrama; Prática de grupo; Ajustamento social}

1 Mood Disorders Unit (Grupo de Estudos de Doenças Afetivas - GRUDA), Department and Institute of Psychiatry, Medical School, Universidade de São Paulo (USP), São Paulo, (SP) Brazil

2 Bipolar Disorders Research Group (Projeto de Assistência e Pesquisa em Transtorno Bipolar - PROMAN), Department and Institute of Psychiatry, Medical School, Universidade de São Paulo (USP), São Paulo, (SP) Brazil

Financing: None

Conflict of interests: None

Submitted: 19 April 2005

Accepted: 14 October 2005

\section{Correspondence}

Elisabeth Maria Sene Costa

Av. Brig. Faria Lima, 1572, conj ${ }^{\circ} 1514$, Pinheiros

01452-908 São Paulo, SP, Brazil

Phone/fax: (55 11) 3813-3190

E-mail: sponteam@terra.com.br 


\section{Introduction}

Major depressive disorder (MDD) is a serious worldwide health problem, accounting for approximately $12 \%$ of all mental and neurological disorders. ${ }^{1}$ The efficacy of antidepressant drugs has contributed to higher rates of remission and lower rates of recurrence, yet psychotherapeutic approaches also play an important role in the treatment of MDD. ${ }^{2}$ Some authors reported that there is a qualitative difference in their therapeutic effects, ${ }^{2}$ or that psychotherapy may improve compliance with pharmacotherapy, improve response rates, and help to suppress specific symptoms. ${ }^{3}$

The three most-used psychotherapeutic approaches are cognitive-behavioral therapy (CBT), interpersonal therapy (IP) and behavioral therapy (BT), although several types of brief psychodynamic psychotherapies have also shown good results. ${ }^{4}$ Brief and focal psychodramatic psychotherapy is a structured form of psychodramatic psychotherapy suitable for crisis situations, having focused objectives. ${ }^{4}$ One such target can be depressive symptoms.

Psychodramatic psychotherapy (PP) is a psychotherapeutic approach based upon the phenomenological-existential method developed by Jacob Levy Moreno in the 1930s. PP deals specifically with human relations and its singularities. ${ }^{5}$ Interrelations between participants and role-playing can lead patients to create new solutions to a given established situation, yielding a therapeutic result. PP has been widely used in the treatment of a variety of psychiatric conditions since the 1930s, although it was only in the last 15 years that more systematic and structured research has been conducted to evaluate the role of PP in psychiatric disorders. To date, no controlled studies focusing PP on depression have been conducted. In the literature search, only six case reports were retrieved. .-11 $^{-}$ Hence, the objective of this paper is to evaluate the impact of individual and group focal psychodramatic psychotherapy in combined treatment of major depressive disorder patients.

\section{Method}

Sixty-two depressed (DSM-IV) outpatients were recruited at the Mood Disorders Unit of the University of São Paulo. Adults aged from 18 to 60, met DSM-IV criteria for mild to moderate major depressive disorder, were receiving pharmacotherapy for depression, and were then enrolled into two groups, composed of ten patients each. The first 10 eligible patients were allocated to the psychotherapic group, being the next 10 allocated to the control group.

Patients with mood disorders other than MDD, including severe MDD and mental disorders due to a medical condition, as well as cognitive, substance-related, psychotic, personality disorders, and individuals with mental retardation were excluded from this study.

All patients were evaluated with the Hamilton Depression Scale - 17 items (HAM-D ${ }_{17}$ ) and with the Social Adjustment Scale - Self Report (SASSR), by an independent and trained psychiatrist. HAM-D ${ }_{17}$ allows measurement of change in depressive symptoms. SASSR is a measure of social adjustment, providing an indirect measure of psychiatric morbidity.

Sociodemographic variables were assessed at baseline. The number of medications in use was evaluated both at baseline and endpoint. All patients were already on medication. This study was not designed for controlling medication use.

The two treatment groups were:

Psychotherapic psychotherapeutic group (PG): 10 patients took part in 4 individual sessions of psychodramatic psychotherapy (PP), and 24 group PP sessions. Psychodramatic sessions were carried out by a psychodramatist and an auxiliary psychotherapist ('auxiliary-ego').

Control group (CG): 10 patients were kept on pharmacotherapy alone, in a naturalistic approach.

During psychodramatic sessions, patients portray situations, subsequently discussing the impact on emotions and actions of the dramatized situations. Two main aspects are assessed: social relations and social roles.

Patients were further evaluated by HAM-D $D_{17}$ and SASSR after the psychodramatic sessions and 28 weeks after baseline. Patients were classified according to treatment response measured by $\mathrm{HAM}-\mathrm{D}_{17}$ : remission (score $<7$ ), response (lowering of HAM-D 17 scores $\geqslant 50 \%$ ), partial response (lowering of $\mathrm{HAM}-\mathrm{D}_{17}$ scores by $\geqslant 25 \%$ and $\leqslant 50 \%$ ), no response (lowering of HAM-D ${ }_{17}$ scores $\leqslant 25 \%$ ) and worsening. SASSR scores were classified as increased, normalized or reduced. These classifications were performed at endpoint and baseline.

The Student t-test was used to compare mean changes between endpoint and baseline, and to compare schooling years, age of onset of the disorder and age of patients. Sociodemographic variables and treatment response measured by HAM-D ${ }_{17}$ and SASSR were compared using Fisher's exact test. The differences between baseline and endpoint HAM and SASSR scores were assessed by the subtraction of the endpoint from baseline value, divided by the baseline value. Mann-Whitney test was used to compare the number of medications at baseline and endpoint. The significance level adopted was 0.05.

The research protocol was approved by the institution's Ethics Committee, and all participants signed an informed consent before entering the study.

\section{Results}

Both groups were comparable in terms of gender, ethnic background, marital status, occupational status, age, age of onset of the disorder and years of schooling. Similarly, the number of medications both at baseline and at endpoint did not show significant differences. All patients in both groups were on medication prior to the study, and there was no significant difference regarding the time spent on medications. The mean percentual change of HAM-D $D_{17}$ scores between endpoint and baseline was $31.62 \%$ ( \pm 19.40$)$ and 14.33 ( \pm 47.62) for the psychotherapeutic and the control groups, respectively. These results showed a marked difference, with an important level of significance $(p=0.0154)$. Moreover, the results indicate that the final mean HAM-D scores for the control group actually increased. The mean percentual change of SASSR between endpoint and baseline was $18.48( \pm 8.49)$ and $0.88( \pm 20.78)$ for psychotherapeutic and control groups, respectively. These results also showed a significant difference ( $p=0.0291)$. Mean percentual changes in HAM-D17 and SASSR scores are presented in Figure 1.

Further analysis of HAM-D 17 scores showed that $20 \%$ of patients in the psychotherapeutic group achieved complete remission after the therapeutic interventions, whilst $20 \%$ responded to the treatments, $50 \%$ had partial responses, and $10 \%$ had no response. In the control group, no patients remitted, $10 \%$ responded to the treatment, $10 \%$ had partial responses, $50 \%$ did not respond, whilst $30 \%$ reported a worsening of depressive symptoms, reflected in an increase in the mean final HAM- $D_{17}$ score. A reduction in SASSR scores was observed in most patients in the psychotherapeutic group. 
(a)

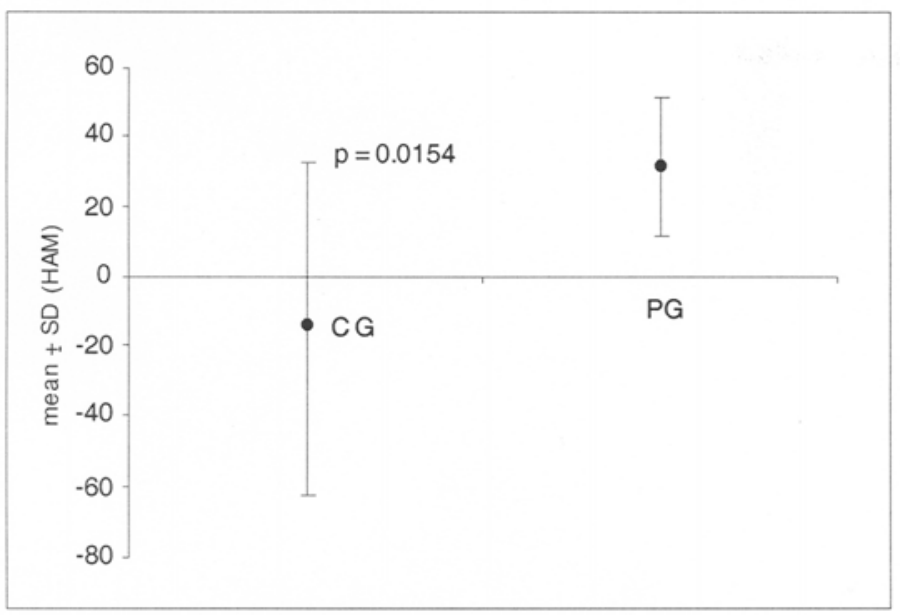

(b)

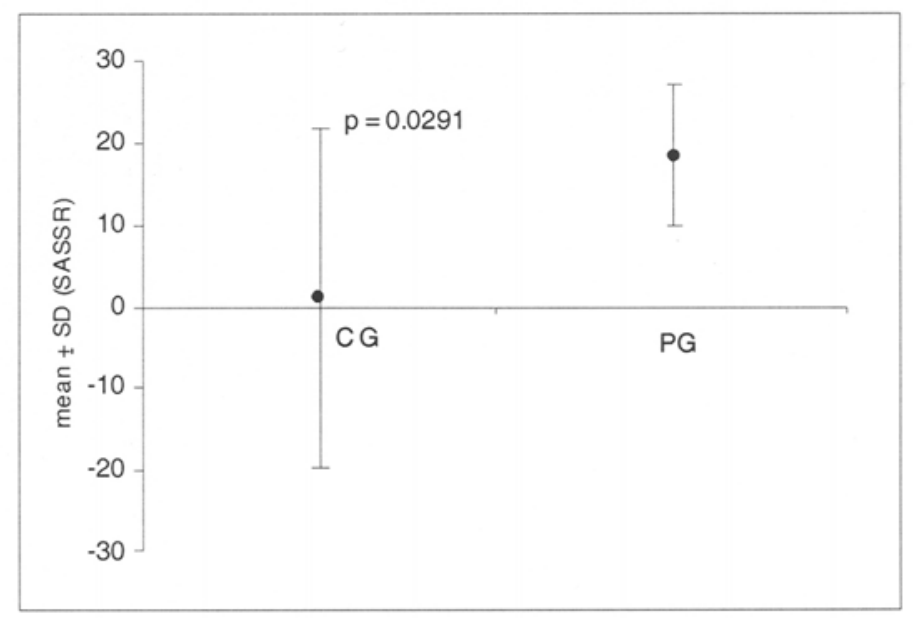

(a) HAM-D; (b) SASSR

$S D=$ standard deviation; $C G$ = control group; $P G=$ psychotherapic group

Figure 1 - Mean percentual changes between endpoint and baseline HAM- $D_{17}$ and SASSR scores and heir respective levels of significance

\section{Discussion}

In this study, treatment response measured by HAM-D 17 and SASSR was significantly better in the psychotherapeutic group, which indicates that PP might be effective as an adjunctive treatment for MDD. This is a valuable contribution to the literature, considering that this psychotherapeutic method has been not studied before in MDD. Our study demonstrates its efficacy according to the higher levels of evidence. On the other hand, there are countless individual cases of individuals who had clinical benefits with psychodramatic psychotherapy. Most of the initially-enrolled patients had psychiatric comorbidities and therefore did not meet inclusion criteria to participate in this study. Other important limitation regards to sample size. Relations between therapists and group colleagues can be impaired if the group has an excessive number of participants. The sample's size was not previously calculated, and the number of patients was determined to fit an adequate group size, in order to enable psychodramatic psychotherapy sessions. The relatively small sample size might have contributed to the great heterogeneity of the results found, indicated by large standard deviations.

As this was a naturalistic study, a control group without any psychotherapic intervention was used, since a comparison group enhances the validity of results. Although it cannot be asserted that results would be different, the use of a 'placebo control group', is, at least theoretically, more adequate to make comparisons between psychotherapeutic groups. ${ }^{12}$ The use of an active control group (i.e., a group that receives another psychotherapy technique with evidence of efficacy) could also have had some influence on results. The naturalistic approach also hindered a randomization, as well as the study design (without an active or placebo control group). Lack of an appropriate randomization might have led to a selection bias.
The lack of classification of the subtype of the depressive episodescan also be considered a limitation of the study, although there is no indication supporting that this could have had impact on our results. In this study, the severity of the depressive episode was measured by the HAM-D ${ }_{17}$. We have considered 7 as the cutoff score for depression on this scale, as most of the current studies on this subject do. This is a limitation, since very mild depressions show significant spontaneous remission rates. However, only two patients in our study had $H A M-D_{17}$ scores $\leqslant 12$. Of note SASSR is, in fact, a social adjustment scale, providing an indirect measure of psychiatric morbidity, which assesses the impact of symptoms both on quality of life and on social adjustment.

It was not the objective of this study to evaluate the response to medication; therefore, the use of medication was not a controlled variable. Although this feature could have led to a bias, measures of the number of medications did not show significant differences between groups, suggesting that this aspect was not expressive.

Finally, one must consider that all psychotherapies display specific and inespecific factors that can influence its efficacy. The patient-therapist relationship might be particularly determinant. Besides, it is well known that more attention is given to experimental than to control groups, particularly in open studies. This study was subjected to both of these limitations.

\section{Conclusions}

Our findings provide evidence that focal psychodramatic psychotherapy might be effective, when combined with pharmacotherapy, in the treatment of major depressive disorder. However, further research is necessary to consolidate the role of psychodramatic psychotherapy as an option in the treatment of MDD and other mental disorders. 


\section{References}

1. Organização Pan-Americana da Saúde e Organização Mundial da Saúde. Relatório sobre a Saúde no Mundo 2001. Saúde Mental: Nova Concepção, Nova Esperança. [citado mar 21 2005]. Disponível em: http://www.psiqweb.med.br/acad/oms1.html.

2. Hirschfeld RMA, Goodwin FK. Transtornos do humor. In: Talbott J, Hales R, Yudofky S, editores. Tratado de Psiquiatria. Porto Alegre: Artes Médicas; 1992. p. 301-28.

3. Pampallona S, Bollini P, Tibaldi G, Kupelnick B, Munizza C. Combined pharmacotherapy and psychological treatment for depression: a systematic review. Arch Gen Psychiatr. 2004;61(7):714-9.

4. Ferreira-Santos E. Psicoterapia breve. Abordagem sistematizada de situações de crise. 3a ed. São Paulo: Ágora; 1997.

5. Moreno JL. Psicodrama. São Paulo: Cultrix; 1975.

6. Ackerman M, Ackerman S. The use of psychodrama in a post-partum depression. J Am Coll Neuropsychiatr. 1962;1:67-70.

7. Burwell D. Psychodrama and the depressed elderly. Can Nurse. 1977;73(4):54-5.

8. Carman MB, Nordin SR. Psychodrama: a therapeutic modality for the elderly in nursing homes. Clin Gerontol. 1984;3(1):15-24.

9. Diniz JT. Depressão: um distúrbio da agressividade? In: Anais do $5^{\circ}$ Congresso Brasileiro de Psicodrama; 1986 Maio 15-20; Caldas Novas: Goiás; 1986. p. 138.

10. Rezaeian MP, Sem AK, Sem Mazumdar DP. The usefulness of psychodrama in the treatment of depressed patients. Indian J Clin Psychol. 1997;24(1):82-8.

11. Antonio R. Ação dramática e intersubjetividade: psicodrama bipessoal com uma paciente deprimida. Rev Bras Psicodr. $2002 ; 10(2): 23-52$.

12. Heimberg RG, Dodge CS, Hope DA, Kennedy CR, Zollo LJ, Becker RE. Cognitive behavioral group treatment for social phobia: comparison with a credible placebo control. Cognit Ther Res. 1990;14(1):1-23. In: Knijnik DZ, Kapczinski F, Chachamovich E, Margis R, Eizirik CL. Psicoterapia psicodinâmica em grupo para fobia social generalizada. Rev Bras Psiquiatr. 2004;26(2):7781. 